Original article

\title{
The prevalence and severity of 25-(OH)-vitamin D insufficiency in HCV infected and in HBV infected patients: a prospective study
}

\author{
Aleksandra Berkan-Kawińska, Ewa Koślińska-Berkan, Anna Piekarska \\ Department of Infectious Diseases and Hepatology, Medical University of Lodz, Lodz, Poland
}

\begin{abstract}
Aim of the study: To assess the prevalence and severity of vitamin $D$ insufficiency in patients with hepatitis $C$ virus (HCV) infection and in patients with hepatitis B virus (HBV) infection.

Material and methods: This prospective study included 90 patients with chronic hepatitis $C$ and 35 patients with chronic hepatitis B admitted to the Infectious Diseases Department between March 2013 and May 2014. Patients with chronic liver disease other than viral hepatitis, HIV co-infection, advanced liver disease and a history of diseases influencing vitamin D status were excluded. Serum vitamin D measurement as well as liver function, viral load, HCV genotype, interleukin 28 and liver fibrosis assessments were performed.

Results: In all patients, the mean vitamin D serum concentration was $18.8( \pm 8.9) \mathrm{ng} / \mathrm{ml}$. The mean vitamin D level in HBV infected patients was lower than in HCV infected patients $(17.6 \mathrm{ng} / \mathrm{ml} \mathrm{vs.} 19.3 \mathrm{ng} / \mathrm{ml} ; p=0.43)$. Vitamin D status was assessed in relation to viral load, HCV genotype, interleukin 28 and sex, but the differences were not significant. In both groups, serum vitamin D levels were significantly lower in winter compared to summer $(14.2 \mathrm{ng} / \mathrm{ml}$ vs. $23.9 \mathrm{ng} / \mathrm{ml}$ in patients infected with HCV [p<0.000001] and $14.7 \mathrm{ng} / \mathrm{ml} \mathrm{vs.} 23.8 \mathrm{ng} / \mathrm{ml}$ in patients infected with HBV $[p<0.001])$.

Conclusions: Our study showed that in patients with chronic hepatitis $C$ or chronic hepatitis $B$, insufficient $25(\mathrm{OH}) \mathrm{D}$ concentrations occur very often, but are not associated with poor virological characteristics. The only factor influencing the vitamin $D$ level was the season.
\end{abstract}

Key words: vitamin D deficiency, hepatitis B, hepatitis C, antiviral treatment.

\section{Address for correspondence}

Aleksandra Berkan-Kawińska, Department of Infectious Diseases and Hepatology, Medical University of Lodz, 1/5 Kniaziewicza St., 91-347 Lodz, Poland, phone/fax: +48 42251 62 65, e-mail: kchzak@csk.umed.lodz.pl

\section{Introduction}

Vitamin D, a fat-soluble steroid prohormone, is a subject of continued interest to researchers from all fields of medicine. It is synthetized from an inactive metabolite 7-dehydrocholesterol which undergoes two successive hydroxylations: to 25-hydroxyvitamin D $(25(\mathrm{OH}) \mathrm{D})$ in the liver and to 1,25 -dihydroxyvitamin $\mathrm{D}$ $\left(1,25(\mathrm{OH})_{2} \mathrm{D}\right)$ in the kidneys. The vitamin $\mathrm{D}$ serum level is usually defined by the concentration of $25(\mathrm{OH}) \mathrm{D}$.

Vitamin D regulates calcium and phosphate balance in the blood as well as maintains proper bone minera- lization. However, in the last few years it has been observed that vitamin $\mathrm{D}$ plays also a role in modulating immune responses, suppression of cell growth, protection from colorectal and prostate cancer and control of insulin secretion as well as muscle and nervous system function [1]. Similarly, although vitamin D synthesis is dependent mostly on sun exposure, its deficiency has been observed in many systemic diseases, such as Parkinson's disease [2], diabetes mellitus [3], cardiovascular diseases [4] and systemic lupus erythematosus [5].

As $25-(\mathrm{OH})$-vitamin $\mathrm{D}$ is synthetized in the liver, hepatic damage may also lead to a decrease in its serum 
concentrations. It has been reported that in patients with chronic liver disease (including chronic hepatitis $\mathrm{C}$, cirrhosis related to hepatitis $\mathrm{C}$ virus $[\mathrm{HCV}]$ infection and cirrhosis unrelated to HCV infection), a low vitamin $\mathrm{D}$ serum concentration is a very common condition present in $92 \%$ of the patients, about one third of which suffers from a severe vitamin D deficiency [6]. On the other hand it has been observed that adding vitamin $\mathrm{D}$ to conventional pegylated interferon $\alpha /$ ribavirin therapy for treatment-naive patients with chronic HCV genotype 1 infection significantly improves the viral response [7].

Because of a strong association between sunlight exposure and vitamin D deficiency, Poland, located in the high latitude area, is a country where low vitamin D serum concentrations are commonly observed especially during winter months [8]. However, the frequency of vitamin D insufficiency in the Polish population of patients infected with $\mathrm{HCV}$ or HBV has not yet been described. We performed this prospective study in order to assess the incidence and severity of vitamin $\mathrm{D}$ deficiency in patients infected with HCV or HBV compared to healthy controls.

\section{Material and methods}

This prospective study included 125 patients aged 18-91 admitted to the Infectious Diseases and Hepatology Department between March 2013 and May 2014. There were 90 ( 34 males and 56 females) patients with chronic hepatitis $C$ and 35 (17 males and 18 females) patients with chronic hepatitis $\mathrm{B}$.

The inclusion criteria were as follows: chronic infection with HCV or HBV confirmed by the presence of serum HCV RNA or HBV DNA, respectively, compensated liver function, no history of previous antiviral treatment and no history of vitamin $\mathrm{D}$ supplementation in the 3 months preceding serum $25(\mathrm{OH}) \mathrm{D}$ level measurement. Patients with chronic liver disease other than hepatitis $\mathrm{C}$ or hepatitis B, HIV co-infection, advanced liver disease (Child-Pugh score $>6$ ) and history of diseases influencing the vitamin $\mathrm{D}$ status (chronic renal disease, malabsorption syndrome) were excluded. Chronic infection with HBV was defined as detectable hepatitis $B$ surface antigen ( $\mathrm{HBsAg}$ ) and HBV DNA $\geq 6$ months, while chronic infection with HCV was defined as detectable HCV RNA $\geq 6$ months. A full history was taken and physical examination was performed for all members of study groups.

All patients with chronic hepatitis B or chronic hepatitis $\mathrm{C}$ were subjected to following investigations: serum alanine transaminase (ALT), $\gamma$-glutamyl transferase (GGTP), albumins (ALB), total bilirubin (BIL-T), platelet count (PLT), hemoglobin $(\mathrm{Hb})$ and internatio- nal normalized ratio (INR). Assessment of liver fibrosis based on liver biopsy was performed in 55/125 patients. Biopsy specimens were evaluated by an experienced pathologist. Fibrosis staging score was assessed using Batts-Ludwig scale.

The diagnosis of HCV infection was based on the positive result of the qualitative HCV RNA test. Quantification of HCV RNA was performed by quantitative real-time polymerase chain reaction (qPCR). The diagnosis of HBV infection was based on the quantitation of HBV DNA by qPCR. Qualitative and quantitative assessments of HCV RNA and HBV DNA were performed using COBAS ${ }^{\bullet}$ AmpliPrep/COBAS $^{\bullet} \mathrm{TaqMan}^{\circledR}$ System (Roche). In HCV-infected patients the HCV genotype was determined by LINEAR ARRAY Hepatitis C Virus Genotyping Test (Roche). Some patients with chronic hepatitis $\mathrm{C}$ had also their IL-B28 status determined.

Serum 25(OH)D measurement was performed by chemiluminescent immunoassay (CLIA). Each patient had only one examination and there was no follow-up regarding vitamin $\mathrm{D}$ levels during the study period. The target serum vitamin $\mathrm{D}$ concentration was defined as $30-50 \mathrm{ng} / \mathrm{ml}$, suboptimal status as $20-30 \mathrm{ng} / \mathrm{ml}$ and deficiency as $<20 \mathrm{ng} / \mathrm{ml}$ [9]. As the study period exceeded one year, it was possible to assess the seasonal differences in 25(OH)D serum concentrations. For this purpose all study patients were divided into two groups based on the time of serum vitamin $\mathrm{D}$ assessment: autumn-winter (November-April) and spring-summer (May-October).

Quantitative data were expressed as mean and range. The distribution of the variables in the study subgroups was evaluated with Shapiro-Wilk test. For comparisons of variables with normal and other than normal distributions, $t$-Student and $U$ Mann-Whitney tests were used, respectively. To assess the differences between frequency of vitamin D target, suboptimal and deficient concentrations in study groups, a $\chi^{2}$ test was used. A difference was considered significant if the probability $(p)$ was $<0.05$. The ethical committee of the Faculty of Medicine, Medical University of Lodz, approved the study and informed written consent was obtained from every patient. The procedures followed were in accordance with the Helsinki Declaration of 1975.

\section{Results}

Demographics and clinical characteristics of the whole study group are presented in Table 1, while virologic characteristics of $\mathrm{HCV}$ and HBV infected patients in Tables 2 and 3, respectively.

In all 125 patients, the mean $25(\mathrm{OH}) \mathrm{D}$ serum concentration was $18.8( \pm 8.9) \mathrm{ng} / \mathrm{ml}$. The mean vitamin D 
Table 1. Characteristics of the study group

\begin{tabular}{|c|c|c|}
\hline Parameter & HCV group $(n=90)$ & HBV group $(n=35)$ \\
\hline \multicolumn{3}{|l|}{ Age (years) } \\
\hline Mean (range) & $41(18-91)$ & $33(20-56)$ \\
\hline \multicolumn{3}{|l|}{ Sex } \\
\hline Males, $n(\%)$ & $34(39)$ & $17(49)$ \\
\hline Females, $n(\%)$ & $56(61)$ & $18(51)$ \\
\hline \multicolumn{3}{|l|}{ ALT (IU/ml) } \\
\hline Mean (range) & $71(8-359)$ & $51(10-344)$ \\
\hline \multicolumn{3}{|l|}{ PLT (× 109/I) } \\
\hline Mean (range) & $\begin{array}{c}195696 \\
(46000-404000)\end{array}$ & $\begin{array}{c}201062 \\
(90000-314000)\end{array}$ \\
\hline \multicolumn{3}{|l|}{ INR } \\
\hline Mean (range) & $1.03(0.69-2.5)$ & $0.94(0.79-1.35)$ \\
\hline \multicolumn{3}{|l|}{$\mathrm{Hb}(\mathrm{mg} / \mathrm{dl})$} \\
\hline Mean (range) & $14.1(9.7-16.6)$ & $14.6(11.6-18.3)$ \\
\hline \multicolumn{3}{|l|}{ GGTP (U/l) } \\
\hline Mean (range) & $69(8-399)$ & $56.7(9-868)$ \\
\hline \multicolumn{3}{|l|}{$\mathrm{ALB}(\mathrm{U} / \mathrm{I})$} \\
\hline Mean (range) & $4.34(3.46-5.33)$ & $4.58(3.70-5.10)$ \\
\hline \multicolumn{3}{|l|}{ BIL-T (mg/dl) } \\
\hline Mean (range) & $0.66(0.22-2.32)$ & $0.99(0.2-4.17)$ \\
\hline
\end{tabular}

level in HBV infected patients was lower than in HCV infected patients $(17.6 \mathrm{ng} / \mathrm{ml}$ vs. $19.3 \mathrm{ng} / \mathrm{ml})$. The difference between the groups was not statistically significant $(p=0.43)$. The frequency of the vitamin D target serum level, suboptimal level and deficiency in all study groups is presented in Table 4 .

\section{Hepatitis C patients group}

\section{5(OH)D level and baseline HCV RNA}

Baseline quantitative HCV RNA assessment was performed in 54 of $90(60 \%)$ patients. In the analysis of
Table 2. Virologic characteristics of HCV infected patients

\begin{tabular}{lc}
\hline Parameter & HCV group $(\boldsymbol{n}=90)$ \\
\hline $\begin{array}{l}\text { Fibrosis staging score according } \\
\text { to Batts-Ludwig scale, } n(\%)\end{array}$ \\
\hline SO/1/2 & $42(91)$ \\
\hline S3/4 & $4(9)$ \\
\hline Missing & 54 \\
\hline Genotype, $n(\%)$ & $71(87)$ \\
\hline 1 & $0(0)$ \\
\hline 2 & $10(12)$ \\
\hline 3 & $1(1)$ \\
\hline 4 & $0(0)$ \\
\hline 5,6 & 8 \\
\hline Missing & 1178104 \\
\hline Viral load (IU/ml) & $25(15500-387000)$ \\
\hline mean & $29(410000-6630000)$ \\
\hline$<400000, n$ (range) & 36 \\
\hline$\geqslant 400000, n$ (range) & $14(25)$ \\
\hline Missing & $43(75)$ \\
\hline Interleukin 28 status, $n(\%)$ & 33 \\
\hline CC & \\
\hline Missing $/ T$ & \\
\hline
\end{tabular}

Table 3. Virologic characteristics of HBV infected patients

\begin{tabular}{lc}
\hline Parameter & HBV group $(\boldsymbol{n}=35)$ \\
\hline $\begin{array}{l}\text { Fibrosis staging score according } \\
\text { to Batts-Ludwig scale, } n(\%)\end{array}$ \\
\hline F0/1/2 & $7(78)$ \\
\hline F3/4 & $2(22)$ \\
\hline Missing & 26 \\
\hline Viral load (copies/ml) & 716258 \\
\hline Mean & $17[(<116)-8788]$ \\
\hline$<10000, n$ (range) & $18(16063-15364800)$ \\
\hline$\geqslant 10000, n$ (range) & 0 \\
\hline Missing &
\end{tabular}

Table 4. The incidence of the vitamin D target serum level, suboptimal level and deficiency in study groups

\begin{tabular}{lccccccc} 
Vitamin D concentration & \multicolumn{2}{c}{ HCV group } & \multicolumn{2}{c}{ HBV group } & \multicolumn{2}{c}{ Total } & \multirow{p}{*}{$\boldsymbol{p}$ value } \\
\cline { 2 - 7 } & $\boldsymbol{n}$ & $\%$ & $\boldsymbol{n}$ & $\%$ & $\boldsymbol{n}$ & $\%$ & \\
\cline { 2 - 7 } Target value & 13 & 14 & 2 & 5 & 15 & 12 & \multirow{2}{*}{0.40} \\
\hline Suboptimal level & 23 & 26 & 10 & 29 & 33 & 26 & \\
\hline Deficiency & 54 & 60 & 23 & 66 & 77 & 62 & \\
\hline
\end{tabular}

$p$ value was calculated using $\chi^{2}$ test

$H C V$ - hepatitis C virus, HBV - hepatitis B virus 
the association between HCV RNA and vitamin D serum concentration we used the cut-off value of $400000 \mathrm{IU} / \mathrm{ml}$ [10]. In patients with baseline HCV RNA $<400000 \mathrm{IU} / \mathrm{ml}(n=25 ; 46 \%)$ and $\geq 10000$ copies/ml $(n=29 ; 54 \%)$, mean vitamin D concentrations were $20.1 \mathrm{ng} / \mathrm{ml}$ and $17.9 \mathrm{ng} / \mathrm{ml}$, respectively. The difference between groups was not statistically significant $(p=0.44)$.

\section{5(OH)D level and HCV genotype}

$\mathrm{HCV}$ genotype $(\mathrm{G})$ was determined in 82 of 90 (91\%) patients. In the group of HCV G1 infected patients $(n=71 ; 87 \%)$, the mean vitamin $\mathrm{D}$ serum level was $18.9 \mathrm{ng} / \mathrm{ml}$, while in the group of patients with HCV G3 chronic infection $(n=10 ; 12 \%)$, the mean vitamin D serum level was $24.6 \mathrm{ng} / \mathrm{ml}$. The dif-

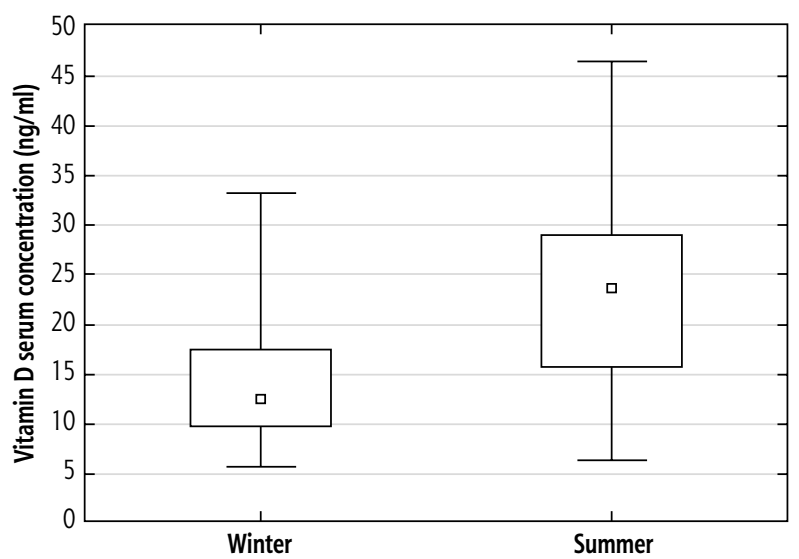

Fig. 1. Mean 25-(OH)-vitamin D serum concentrations in the HCV study group according to season. The mean vitamin $D$ serum concentrations in winter and summer months were $14.2( \pm 6.2)$ and $23.9( \pm 9.1) \mathrm{ng} / \mathrm{ml}$, respectively.

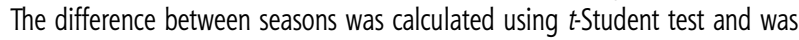
statistically significant $(p<0.000001)$

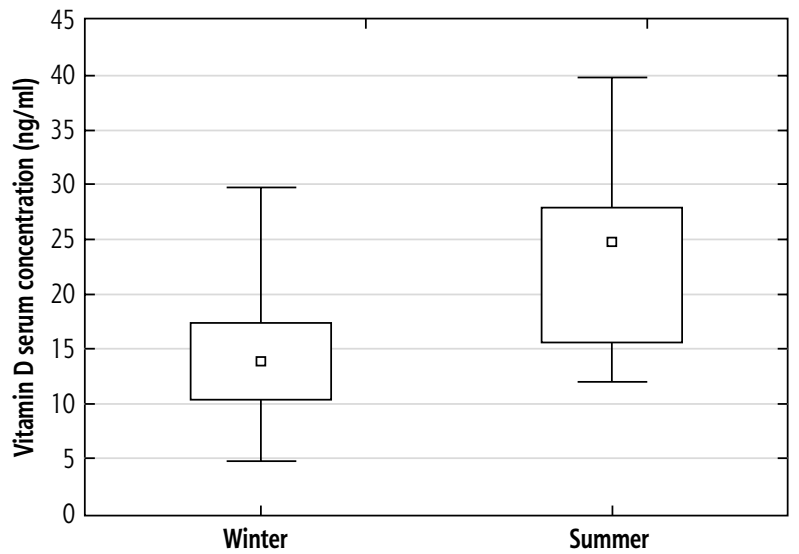

Fig. 2. Mean $25-(\mathrm{OH})$-vitamin $\mathrm{D}$ values in the $\mathrm{HBV}$ study group according to season. The mean $25(\mathrm{OH}) \mathrm{D}$ serum concentrations in winter were significantly lower than mean $25(\mathrm{OH}) \mathrm{D}$ serum concentrations in summer $(14.7 \pm 5.6 \mathrm{ng} / \mathrm{ml}$ and $23.8 \pm 8.7 \mathrm{ng} / \mathrm{ml}$, respectively; t-Student test $p<0.001$ ) ference was not significant ( $p=0.17$ ). The small number of patients infected with HCV of other genotypes (G4: one patient; G2,5,6: no patients) did not allow us to include them in any statistical analysis.

\section{5(OH)D level and baseline IL-B28}

In 57 out of 90 patients (63\%) with chronic hepatitis $\mathrm{C}$, the analysis of interleukin 28 status was performed. Genotypes CC and CT/TT were observed in $14(25 \%)$ and $43(75 \%)$ patients, respectively. When vitamin $\mathrm{D}$ was compared between the groups, higher $25(\mathrm{OH}) \mathrm{D}$ serum levels were observed in $\mathrm{CT} / \mathrm{TT}$ group than in CC group (21.1 ng/ml vs. $16.5 \mathrm{ng} / \mathrm{ml}$ ), however, the difference between both groups was not statistically significant $(p=0.08)$.

\section{5(OH)D level and season}

To assess the relationship between $25(\mathrm{OH}) \mathrm{D}$ serum level and season, the study period was divided into autumn-winter months (November-April; $n=43 / 90$, $48 \%$ ) and spring-summer months (May-October; $n=47 / 90,52 \%)$ depending on the date of vitamin D testing. The mean vitamin $\mathrm{D}$ serum concentrations in autumn-winter and spring-summer months were 14.2 and $23.9 \mathrm{ng} / \mathrm{ml}$, respectively (Fig. 1). The difference between seasons was statistically significant $(p<0.000001)$.

\section{5(OH)D level and sex}

The present study demonstrated that although in the group of patients with chronic hepatitis $C$, mean vitamin $\mathrm{D}$ serum concentrations in women $(n=54$, $61 \% ; 17.9 \mathrm{ng} / \mathrm{ml})$ were lower than in men $(n=36,39 \%$; $21.5 \mathrm{ng} / \mathrm{ml})$, the difference was not statistically significant $(p=0.26)$.

\section{Hepatitis B patients group}

\section{5(OH)D level and baseline HBV DNA}

Baseline quantitative HBV DNA assessment was performed in all 35 patients from the HBV study group. To evaluate the association between $25(\mathrm{OH}) \mathrm{D}$ serum concentration and baseline HBV DNA we used the cut-off value of 10000 copies/ml [11]. In patients with baseline HBV DNA < 10000 copies/ml $(n=17$; $49 \%)$ and $\geq 10000$ copies/ml $(n=18 ; 51 \%)$ mean vitamin D concentrations were $18.3 \mathrm{ng} / \mathrm{dl}$ and $16.9 \mathrm{ng} / \mathrm{dl}$, respectively. The difference between groups was not statistically significant $(p=0.67)$. 


\section{5(OH)D level and season}

To assess the $25(\mathrm{OH}) \mathrm{D}$ serum level according to the season in HBV infected patients we used the same division pattern as in patients with chronic $\mathrm{HCV}$ infection: autumn-winter months (November-April; $n=24 / 35,69 \%$ ) and spring-summer months (MayOctober; $n=11 / 35,31 \%)$, depending on the date of vitamin $\mathrm{D}$ testing. The mean $25(\mathrm{OH}) \mathrm{D}$ serum concentrations in autumn-winter were significantly lower than mean $25(\mathrm{OH}) \mathrm{D}$ serum concentrations in spring-summer $(14.7 \mathrm{ng} / \mathrm{ml}$ and $23.8 \mathrm{ng} / \mathrm{ml}$, respectively; $p<0.001)$ (Fig. 2).

\section{5(OH)D level and gender}

Among 35 patients with chronic HBV infection there were $17(49 \%)$ men and 18 (51\%) women. The mean 25(OH)D serum levels were $16.1 \mathrm{ng} / \mathrm{ml}$ in women and $19.1 \mathrm{ng} / \mathrm{ml}$ in men. Again, this difference was not significant $(p=0.27)$.

\section{Discussion}

In our study we observed that in patients with chronic hepatitis B or hepatitis $C$, mean serum vitamin D levels are much below normal limits. Hepatitis $B$ patients suffered from a more severe deficiency than hepatitis $\mathrm{C}$ patients, however, the difference was not statistically significant. Moreover, the results of our study suggest that insufficient $25(\mathrm{OH}) \mathrm{D}$ serum concentrations are not associated with poor virological characteristics of the patients and the only factor influencing the vitamin $\mathrm{D}$ level is the season (autumn-winter versus spring-summer) - mean serum vitamin $\mathrm{D}$ levels in HBV or HCV infected patients in the autumn-winter months (November-April) were significantly lower than during spring-summer (May-October).

This observation has already been reported for healthy populations from other European regions, including Ireland [12] and Hungary [13], as well as from other continents, e.g. from Australia [14], but there are not many reports concerning patients with chronic viral hepatitis. In a study conducted on the group of 296 Bulgarian patients with chronic hepatitis C, Gerova et al. [10] reported that the median $25(\mathrm{OH}) \mathrm{D}$ level of the whole cohort was $50.40 \mathrm{nmol} / 1(20.03 \mathrm{ng} / \mathrm{ml})$ and more than $80 \%$ of the patients were vitamin $\mathrm{D}$-insufficient or deficient (the cut-off value of $80 \mathrm{nmol} / 1$ [32 ng/ml] was the same as the value used in our analysis). Moreover, significantly lower $25(\mathrm{OH}) \mathrm{D}$ concentrations (median $32.20 \mathrm{nmol} / \mathrm{l}$ ) were measured during autumn-winter in comparison with those during spring- summer (median $66.4 \mathrm{nmol} / \mathrm{l}$ ). These results remain consistent with the data obtained in our study as we also observed that in patients with chronic hepatitis $\mathrm{C}$ insufficient vitamin $\mathrm{D}$ levels are very common. The mean $25(\mathrm{OH}) \mathrm{D}$ concentration and percentage of patients with an overly low vitamin D level $(19.6 \mathrm{ng} / \mathrm{dl}$ and $86 \%$, respectively) were similar to the values reported by Gerova et al. A statistically significant difference between seasonal serum vitamin $\mathrm{D}$ assessments (autumn-winter vs. spring-summer; $p<0.000001$ ) was also reported.

In our study the same statistically significant association between mean serum $25(\mathrm{OH}) \mathrm{D}$ concentrations and the season was observed also in the group of patients with chronic hepatitis B - in the autumnwinter months (November-April) mean 25(OH)D levels were significantly lower than during spring-summer (May-October). However, the literature lacks reports confirming these results - to our knowledge, it is the first Polish study assessing the incidence of $25(\mathrm{OH}) \mathrm{D}$ deficiency in patients with chronic hepatitis $\mathrm{B}$ and data from the foreign literature are also sparse. In a recently conducted study Yu et al. explored the association between the serum vitamin $\mathrm{D}$ level and liver histology or virological parameters in patients with chronic hepatitis B infection in Southern China [15]. Mean 25-hydroxyvitamin D value in the group of 242 treatment-naïve patients included in the study was $33.90 \mathrm{ng} /$ $\mathrm{ml}$. The percentage of patients with target, suboptimal and deficient concentrations of $25(\mathrm{OH}) \mathrm{D}$ was $59.9 \%$, $31.4 \%$, and $8.7 \%$, respectively. Yu et al. observed that gender, season, age, and viral genotype were independent predictors of vitamin D insufficiency $(<30 \mathrm{ng} / \mathrm{ml})$. Genotype B was associated with a lower vitamin D serum level than genotype $C(p=0.021)$. The authors found no statistically significant correlation between $25(\mathrm{OH}) \mathrm{D}$ and liver fibrosis as well as with viral load.

Contradictory results were obtained by Farnik et al. who reported that low $25(\mathrm{OH}) \mathrm{D}$ serum levels were associated with high levels of HBV replication in patients with chronic hepatitis B [16]. The study was conducted in Frankfurt, Germany. Of 203 treatment-naïve patients with chronic HBV infection, only in 39 (19\%) of all cases vitamin $\mathrm{D}$ concentrations were adequate. The mean vitamin D serum level was $14.4 \mathrm{ng} / \mathrm{ml}$. Vitamin D deficiency was observed in $34 \%$ of the study population. The mean $25(\mathrm{OH}) \mathrm{D}$ serum concentration in patients with HBV DNA < $2000 \mathrm{IU} / \mathrm{ml}$ was significantly higher than in patients with HBV DNA $\geq 2000 \mathrm{IU} / \mathrm{ml}(p<0.00001)$. The statistically relevant association between the presence of hepatitis B early antigen $(\mathrm{HBeAg})$ and lower $25(\mathrm{OH}) \mathrm{D}$ serum levels was also observed $(p=0.0013)$. 
In our study, the mean serum vitamin $\mathrm{D}$ level in HBV infected patients $(17.6 \mathrm{ng} / \mathrm{ml})$ and the frequency of vitamin D deficiency (66\%) as well as suboptimal (29\%) levels were much lower and much higher, respectively, than in the study of Yu et al. On the other hand, the mean vitamin D serum level was comparable to that reported by Farnik et al. The possible explanation of the above-mentioned differences and similarities is that a study of Yu et al. was conducted in Guangzhou, Southern China (latitude $23^{\circ} \mathrm{N}$ ), while a study by Farnik in Frankfurt, Germany (latitude $50^{\circ} \mathrm{N}$, similar to the latitude of Poland $52^{\circ} \mathrm{N}$ ). These observations prove that in patients with chronic hepatitis, vitamin D synthesis is highly latitude-dependent. This observation remains consistent with the results of other studies that prove the significant impact of latitude on the prevalence of vitamin D insufficiency [14].

Similarly to Farnik et al., we also observed that in patients with HBV DNA $<10000$ copies/ml, the vitamin D level was higher than in patients with HBV DNA $\geq 10000$ copies/ml, however in our study the difference was not statistically significant. In our investigation we did not provide the assessment of HBeAg, the presence of which, basing on the results obtained by Farnik et al., was significantly associated with lower serum vitamin D levels. Evaluation of HBsAg in relation to vitamin $\mathrm{D}$ deficiency in patients with chronic hepatitis B could be also useful in view of the results from the study by Mahamid et al. [17] who found a strong correlation between normal vitamin $\mathrm{D}$ levels and spontaneous HBsAg seroclearance. Out of the 53 patients who underwent hepatitis $\mathrm{B}$ antigen seroclearance, in 44 patients $(83 \%)$ the levels of $25(\mathrm{OH}) \mathrm{D}$ were within normal limits compared to 9 patients (17\%) who had vitamin D insufficiency.

The results of our study suggest that also in the group of patients with chronic hepatitis $\mathrm{C}$ their virological characteristics did not influence the vitamin $\mathrm{D}$ level. No significant association between serum $25(\mathrm{OH}) \mathrm{D}$ levels and IL28B status as well as HCV genotype were observed. Moreover, in our study we also assessed the relationship between HCV RNA and vitamin D and although in the group with lower HCV RNA serum vitamin $\mathrm{D}$ concentrations were higher, we did not prove this difference to be statistically important. Similarly, in the study of Spanish patients with chronic hepatitis C, Ladero et al. [18] did not report any statistically significant relationships between $25(\mathrm{OH}) \mathrm{D}$ levels and biochemical liver tests, fibrosis stage and IL28B genotype. The vitamin D deficiency was very common $(77 \%)$ and although vitamin D therapy normalized 25(OH)D levels in all treated patients, it did not modify significantly HCV-RNA serum levels or biochemical tests. However, the data from the literature are more inconsistent. In a study by Amanzada et al. [19] the authors reported that decreased $25(\mathrm{OH}) \mathrm{D}$ levels indicate the severity of hepatic inflammation and fibrosis in patients infected chronically with $\mathrm{HCV}$ type 1 . Moreover, using the same cut-off value of $400000 \mathrm{IU} / \mathrm{ml}$ as in our study Gerova et al. [10] found an inverse relationship between $25(\mathrm{OH}) \mathrm{D}$ and HCV-RNA $(p<0.01)$.

When we compared vitamin D serum levels in patients chronically infected with HBV and in patients chronically infected with $\mathrm{HCV}$ we found that in the latter group $25(\mathrm{OH}) \mathrm{D}$ concentrations were higher. However, the difference was not statistically significant. In comparison of the frequencies of the vitamin D target level, suboptimal level and deficiency between the study populations we found that in both groups, vitamin $\mathrm{D}$ deficiency was the most common condition that occurred in $60 \%$ and in $66 \%$ of $\mathrm{HCV}$ and HBV infected patients, respectively. The target vitamin D concentration was observed only in $14 \%$ and $5 \%$ of the cases. The frequencies of respective vitamin D concentrations did not differ significantly between both study groups.

Similar results were obtained by Farnik et al. [16] who used age- and sex-matched HCV infected patients as the control group in their study of vitamin D in patients with chronic hepatitis B. They also reported that in patients with chronic hepatitis $\mathrm{C}$, the mean vitamin D level, although still low $(18.15 \mathrm{ng} / \mathrm{ml})$, was higher than in patients infected with HBV. Again, the difference was not statistically significant.

The limitations of this study include a small HBV group and lack of comparison to healthy controls. There was also no assessment of $\mathrm{HBeAg}$ in patients with chronic hepatitis $B$ which, in view of the results obtained by Farnik et al. [16] and Mahamid et al. [17], is worth further examination. However, it still seems that in Polish population of patients with chronic hepatitis $\mathrm{B}$ and chronic hepatitis $\mathrm{C}, 25(\mathrm{OH}) \mathrm{D}$ insufficiency is a very common condition and it occurs with similar incidence to comparable populations from geographic regions of the same latitude. In the future a comparison of incidence and severity of vitamin $\mathrm{D}$ insufficiency in healthy controls should be performed as the question if the prevalence and severity of vitamin $\mathrm{D}$ insufficiency among patients with chronic hepatitis is higher than in healthy controls remains unanswered.

Moreover, the results of our study suggest that patients with chronic hepatitis B or C infection could benefit from vitamin $\mathrm{D}$ supplementation. This is particularly true in view of the reports stating that vitamin D deficiency management may improve response 
to treatment at least in patients with chronic hepatitis $\mathrm{C}$ [20]. The impact of 25(OH)D levels and supplementation on antiviral treatment results as well on progression to cirrhosis in Polish population of patients with chronic hepatitis $\mathrm{B}$ and $\mathrm{C}$ should also be a subject to further investigations.

\section{Disclosure}

Authors report no conflict of interest.

\section{References}

1. Dusso AS, Brown AJ, Slatopolsky E. Vitamin D. Am J Physiol Renal Physiol 2005; 289: F8-28.

2. Mehanna R, Scherzer CR, Ding H, et al. Unrecognized vitamin D3 deficiency is common in Parkinson disease: Harvard Biomarker study. Neurology 2014; 82: 1666.

3. Griz LH, Bandeira F, Gabbay MA, et al. Vitamin D and diabetes mellitus: an update 2013. Arq Bras Endocrinol Metabol 2014; 58: 1-8.

4. Marra A, Leoncini G, Mussap M, et al. Severe vitamin D deficiency is associated with frequently observed diseases in medical inpatients. Int J Clin Pract 2014; 68: 647-652.

5. Bogaczewicz J, Sysa-Jedrzejowska A, Arkuszewska C, et al. Vitamin D status in systemic lupus erythematosus patients and its association with selected clinical and laboratory parameters. Lupus 2012; 21: 477-484.

6. Arteh J, Narra S, Nair S. Prevalence of vitamin D deficiency in chronic liver disease. Dig Dis Sci 2010; 55: 2624-2628.

7. Abu-Mouch S, Nimer A, Fireman Z, et al. Vitamin D supplementation improves sustained virologic response in chronic hepatitis C (genotype 1)-naïve patients. World J Gastroenterol 2011; 17: 5184-5190.

8. Kmieć P, Żmijewski M, Waszak P, et al. Vitamin D deficiency during winter months among an adult, predominantly urban, population in Northern Poland. Endokrynol Pol 2014; 65: 105-113.

9. Płudowski P, Karczmarewicz E, Bayer M, et al. Practical guidelines for the supplementation of vitamin $\mathrm{D}$ and the treatment of deficits in Central Europe - recommended vitamin D intakes in the general population and groups at risk of vitamin $\mathrm{D}$ deficiency. Endokrynol Pol 2013; 64: 319-327.

10. Gerova D, Galunska BT, Ivanova II, et al. Prevalence of vitamin D deficiency and insufficiency in Bulgarian patients with chronic hepatitis C viral infection. Scand J Clin Lab Invest 2014; 74: 665-672.

11. Yang Y, Wen F, Li J, et al. A high baseline HBV load and antiviral therapy affect the survival of patients with advanced HBV-related HCC treated with sorafenib. Liver Int $2015 \mathrm{Feb}$ 11; doi: 10.1111/liv.12805 [Epub ahead of print].

12. Hill TR, McCarthy D, Jakobsen J, et al. Seasonal changes in vitamin D status and bone turnover in healthy Irish postmenopausal women. Int J Vitam Nutr Res 2007; 77: 320-325.

13. Bhattoa HP, Bettembuk P, Ganacharya S, et al. Prevalence and seasonal variation of hypovitaminosis $\mathrm{D}$ and its relationship to bone metabolism in community dwelling postmenopausal Hungarian women. Osteoporos Int 2004; 15: 447-451.

14. van der Mei IA, Ponsonby AL, Engelsen O, et al. The high prevalence of vitamin $\mathrm{D}$ insufficiency across Australian populations is only partly explained by season and latitude. Environ Health Perspect 2007; 115: 1132-1139.

15. Yu R, Sun J, Zheng Z, et al. Association between vitamin D level and viral load or fibrosis stage in chronic hepatitis B patients from Southern China. J Gastroenterol Hepatol 2015; 30: 566-574.

16. Farnik H, Bojunga J, Berger A, et al. Low vitamin D serum concentration is associated with high levels of hepatitis B virus replication in chronically infected patients. Hepatology 2013; 58: $1270-1276$.

17. Mahamid M, Nseir W, Abu Elhija O, et al. Normal vitamin D levels are associated with spontaneous hepatitis B surface antigen seroclearance. World J Hepatol 2013; 5: 328-331.

18. Ladero JM, Torrejón MJ, Sánchez-Pobre P, et al. Vitamin D deficiency and vitamin D therapy in chronic hepatitis C. Ann Hepatol 2013; 12: 199-204.

19. Amanzada A, Goralczyk AD, Moriconi F, et al. Vitamin D status and serum ferritin concentration in chronic hepatitis $C$ virus type 1 infection. J Med Virol 2013; 85: 1534-1541.

20. Nimer A, Mouch A. Vitamin D improves viral response in hepatitis C genotype 2-3 naïve patients. World J Gastroenterol 2012; 18: 800-805. 